\title{
Analisis Determinan Cadangan Devisa di Indonesia
}

\author{
Bagus Adhitya \\ Fakultas Ekonomika dan Bisnis, Universitas Wijayakusuma, Purwokerto \\ Correspondence email: bagus.adhitya26@gmail.com
}

\begin{abstract}
Abstrak. Penelitian ini bertujuan menganalisis pengaruh ekspor, impor dan tingkat inflasi terhadap cadangan devisa di Indonesia. Jenis peneilitian ini adalah kuanlitatif. Metode penelitian ini menggunakan regresi liner berganda dengan model Ordinary Least Square. Hasil penelitian menunjukkan bahwa ekspor berpengaruh positif dan signifikan terhadap cadangan devisa. Impor berpengaruh negatif dan signifikan terhadap cadangan devisa. Tingkat inflasi tidak berpengaruh berpengaruh positif terhadap cadangan devisa. Temuan ini mengimplikasikan bahwa pemerintah harus meningkatkan ekspor keluar negeri menekan impor dari produk luar negeri.
\end{abstract}

Kata kunci: Cadangan Devisa; Ekspor; Impor; Tingkat Inflasi

Abstract. This study aims to analyze the effect of exports, imports and inflation rates on foreign exchange reserves in Indonesia. This type of research is quantitative. This research method uses multiple linear regression with the Ordinary Least Square model. The results showed that exports had a positive and significant effect on foreign exchange reserves in Indonesia at 2011-2018. Imports have a negative and significant effect on foreign exchange reserves in Indonesia at 2011-2018. The inflation rate has no positive effect on foreign exchange reserves in Indonesia in 2011-2018. This finding implies that the government must increase exports abroad to suppress imports of foreign products.

Keywords: Foreign Exchange Reservers; Exports; Imports; Inflation Rates

\section{PENDAHULUAN}

Negara-negara maju di dunia terdorong untuk melakukan perdagangan internasional di era global saat ini, dan pesatnya perkembangan teknologi informasi dan komunikasi. Perdagangan internasional dapat meningkatkan pembangunan devisa nasional serta sebagai salah satu sumber pembiayaan pembangunan ekonomi negara. Untuk melihat sejauh mana suatu negara melakukan perdagangan internasional serta lemah kuatnya perekonomian negara dapat dilihat dari cadangan devisa negara tersebut.

Sumber pembiayaan perdagangan luar negeri berasal dari cadangan devisa, di Indonesia cadangan devisa dipertanggung jawabkan oleh bank Indonesia yang telah ditetapkan dalam Undang-Undang no 3 tahun 2004 tentang Bank Indonesia. Bank Indonesia berperan penting dalam mengelola perekonomian di Indonesia khusunya devisa negara. Bank Indonesia dapat melakukan berbagai transaksi devisa dan dapat menerima pinjaman

Cadangan Devisa adalah simpanan oleh bank sentral dan otoritas moneter. Cadangan devisa dapat diartikan sebagai sejumlah valuta asing yang dicadangkan dan dikuasai oleh bank sentral yang di Indonesia dipegang oleh Bank Indonesia sebagai otoritas moneter. Cadangan devisa dapat diketahui dari posisi Balance Of Payment (BOP) atau neraca pembayaran internasional negara tersebut. Semakin banyak devisa yang dimiliki oleh pemerintah dan penduduk suatu negara maka makin besar kemampuan negara tersebut dalam melakukan transaksi ekonomi dan keuangan internasional dan makin kuat pula nilai mata uang suatu negara (Ridho, 2015).

Cadangan devisa dapat menjadi suatu indikator yang penting untuk melihat sejauh mana negara dapat melakukan perdagangan internasional dan untuk menunjukkan kuat lemahnya perekonomian suatu negara. Bank Indonesia (BI) mencatat cadangan devisa Indonesia pada akhir Juni 2019 berada pada angka US\$ 123,8 miliar atau meningkat US\$ 3,5 miliar dibanding bulan sebelumnya. Peningkatan ini merupakan yang tertinggi sepanjang 2019. Pada Mei 2019 tercatat Indonesia mengalami penurunan cadangan devisa sebesar US\$ 4 miliar menjadi US\$ 120,3 miliar dari bulan sebelumnya.

Salah satu faktor yang mempengaruhi cadangan devisa adalah ekspor. Menurut Amir (2005) ekspor adalah perdagangan dengan mengeluarkan barang dari dalam ke luar pabean Indonesia dengan memenuhi ketentuan-ketentuan berlaku. Ekspor merupakan satu dari sekian pekerjaan rumah yang masih harus diselesaikan pemerintah. Secara keseluruhan fundamental ekonomi Indonesia masih baik, namun tetap harus waspada terutama dari faktor eksternal. Kegiatan ekspor suatu negara dapat memperoleh sejumlah nilai uang dalam valuta asing atau biasa disebut dengan istilah devisa, yang juga merupakan salah satu sumber pemasukan negara, sehingga tingkat ekspor mengalami penurunan, maka diikuti dengan ikut menurunnya cadangan devisa yang dimiliki (Agustina dan Reny, 2014).

Faktor berikutnya yang mempengaruhi cadangan devisa adalah impor. Impor adalah kegiatan perdagangan 
internasional yang meliputi kegiatan pengiriman suatu barang dari luar negeri ke seluruh pelabuhan yang ada diseluruh wilayah Indonesia. Kegiatan impor dilakukan guna memenuhi kebutuhan dalam negeri baik berupa pangan maupun untuk kegiatan industri dan lain-lain (Juniantara dan Budhi, 2012). Impor ditentukan oleh kesanggupan atau kemampuan dalam menghasilkan barang-barang yang bersaing dengan barang luar negeri. Di samping itu, sebuah perusahaan yang melakukan impor memerlukan jumlah devisa yang lebih besar untuk membayar transaksi tersebut, sehingga ketersediaan devisa dapat memegang peranan penting di dalam kegiatan impor, suatu negara melakukan impor karena produksi dalam negeri tidak mampu mencukupi kebutuhan sendiri atau bahkan negara sendiri tidak mampu memproduksi (Dananjaya at al.2019). Semakin tinggi tingkat cadangan devisa, dan semakin rendah kemampuan negara tersebut dalam menghasilkan barang- barang tertentu, maka kegiatan impor pun akan semakin tinggi. Hal ini menyebabkan banyaknya kebocoran dalam cadangan devisa (Juniantara dan Budhi, 2012). Hal ini sesuai dengan penelitian sebelumnya oleh Benny (2013),

Inflasi adalah kecenderungan terjadinya peningkatan harga produk-produk secara keseluruhan. Tingkat inflasi yang tinggi biasanya dikaitkan dengan kondisi ekonomi yang terlalu panas (overhead) artinya kondisi ekonomi mengalami permintaan atas produk yang melebihi kapasitas penawaran produknya, sehingga harga-harga cenderung mengalami kenaikan (Kuswantoro, 2017). Inflasi merupakan salah satu faktor yang mempengaruhi tingkat cadangan devisa suatu negara. Jadi, jika inflasi yang terjadi dalam suatu negara tinggi maka harga barang dan juga jasa yang ada di dalam negeri akan tinggi. Hal ini menyebabkan perubahan pada nilai mata uang dan berimbas pada simpanan giro bank umum dan berdampak pada cadangan devisa. Dengan kata lain, semakin tinggi tingkat inflasi yang terjadi maka akan menambah nilai suatu mata uang karena naiknya harga barang dan jasa di pasaran (Putra dan Indrajaya, 2013).

Fokus permasalahan yang diuraikan diatas, menjelaskan pentingnya cadangan devisa bagi negera berkembang seperti Indonesia. Penelitina ini bertujuan menganalisis pengaruh ekspor, impor, dan tingkat inflasi terhadap cadangan devisa di Indonesia tahun 2011 sampai 2018.

\section{METODE}

Jenis data yang digunakan dalam penelitian ini adalah data yang bersifat kuantitatif yaitu data yang berbentuk angka-angka. Sumber data yang digunakan dalam penelitian adalah data sekunder. Data yang digunakan dalam penelitian ini adalah data time series yang diambil dari bulan Januari tahun 2011 sampai dengan Desembar tahun 2018. Variabel dependen dalam penelitian ini adalah cadangan devisa yang diukur dengan satuan Miliar Dollar. Sementara itu, variabel independen dalam penelitian ini adalah 1) ekspor yang diukur dengan satuan Miliar Dollar, 2) impor yang diukur dengan satuan Miliar Dollar, dan 3) inflasi yang diukur dengan satuan persentase.

Teknik analisis data yang digunakan dalam penelitian ini adalah regresi linier berganda dnegan model Ordinary Least Square (OLS) dengan dibantu Software Eviews. Menurut Sugiyono (2012) analisis regresi berganda adalah analisis yang digunakan peneliti, bila bermaksud meramalkan bagaimana keadaan (naik turunnya) variabel dependen (kriterium), bila dua atau lebih variabel independen sebagai faktor prediktor (dinaik turunkan nilainya). Persamaan regresi yang digunakan adalah sebagai berikut:

$$
\begin{aligned}
& \mathrm{CD}_{\mathrm{t}}=\beta_{0}+\beta_{\mathrm{t}} \mathrm{EK}_{1 \mathrm{t}}+\beta_{2} \mathrm{IM}_{2 \mathrm{t}}+\beta_{3} \mathrm{IF}_{3 \mathrm{t}}+e \\
& \text { Keterangan: } \\
& \mathrm{CD} \quad=\text { Cadangan Devisa } \\
& \beta_{0} \quad=\text { Konstanta } \\
& \beta_{1,2,3}=\text { Koefisien regresi } \\
& \mathrm{EK} \quad=\text { Ekspor } \\
& \mathrm{IM} \quad=\text { Impor } \\
& \mathrm{IF} \quad=\text { Inflasi } \\
& e \quad=\text { Standard error } \\
& i \quad=\text { Time series }
\end{aligned}
$$

Uji asumsi klasik terhadap model regresidilakukan agar dapat mengetahui apakah model regresi tersebut merupakan model regresi yang baik atau tidak, model penelitian ini uji asumsi klasik yang digunakan adalah uji normalitas, multikolineritas, heteroskedastisitas, dan autokorelasi (Gujarati dan Porter, 2011).

\section{HASIL DAN PEMBAHASAN}

Uji normalitas bertujuan untuk menguji apakah nilai residual yang telah distandarisasi pada model regresi berdistribusi normal atau tidak (Suliyanto, 2011). Residual dinyatakan normal apabila probabilitas normality yang dihasilkan $\geq$ level of significant $(\alpha=5 \%)$ maka residual dinyatakan berdistribusi normal. Hasil analisis menunjukkan bahwa nilai probability sebesar 0,966 lebih besar dari level of significant $(\alpha=5 \%)$. Dengan demikian dapat dinyatakan bahwa residual pada model dinyatakan berdistribusi normal, sehingga asumsi normalitas terpenuhi

Uji multikolinieritas bertujuan untuk melihat ada tidaknya hubungan yang sangat kuat atau sempurna antar variabel bebas (Suliyanto, 2011). Berikut ini Tabel 1 yang menunjukkan hasil uji multikolinearitas dengan menggunakan Variance Inflation Factor (VIF).

Tabel 1. Uji Multikolinearitas

\begin{tabular}{cccc}
\hline No & Variabel & VIF & Keterangan \\
\hline 1 & Ekspor & 1,817 & Tidak ada multikolinearitas \\
2 & Impor & 1,851 & Tidak ada multikolinearitas \\
3 & Inflasi & 1,035 & Tidak ada multikolinearitas \\
\hline
\end{tabular}

Sumber : Output Regresi 
Tabel 1 menunjukkan bahwa nilai VIF dari semua variabel independen kurang dari 10, sehingga dapat disimpulaan bahwa tidak terhadi multikolinieritas antar variabel independen dalam model regresi.

Uji autokorelasi bertujuan untuk menguji apakah dalam suatu model regresi linear ada korelasi antar kesalahan pengganggu pada periode $t$ dengan kesalahan pada periode t-1 (Suliyanto, 2011). Berdasarkan pengujian nilai Durbin Waston sebesar sebesar 1,884 dengan tingkat signifikan 0,05 . Untuk melihat ada atau tidaknya autokorelasi hasil analisis uji Durbin Waston ini dibandingkan nilai pada tabel Durbin Waston dengan signifikan 0,05 . Setelah dibandingkan dengan nilai tabel diperoleh nilai (dl sebesar 1,6039 dan du sebesar 1,7321). Hasil Durbin Waston 0,650 dibawah nilai dl, sehingga d berada dalam kategori daerah tidak ada autokorelasi.

Uji Heteroskedastisitas bertujuan untuk mengetahui apakah dalam model regresi terjadi ketidasamaan varian dari suatu residual pengamatan ke pengamatan yang lain (Suliyanto, 2011). Berdasarkan uji glejser menunjukkan bahwa nilai probabilitas pada obs*r-squared sebesar 0,0839 lebih besar dari level of significant $(\alpha=5 \%$ atau 0.05 . Dengan demikian dapat dinyatakan terbebas dari uji heteroskedastisitas.

Berikut ini Tabel 2 yang menunjukkan ringkasan hasil regresi dalam penelitian ini

Tabel 2. Hasil Uji Regresi Linier Berganda

\begin{tabular}{clrc}
\hline No & Variabel & Koefisien & P.Value \\
\hline 1 & (Constant) & 0,2451 & 0,0000 \\
2 & Ekspor & 3,6510 & $0,0080^{*}$ \\
3 & Impor & $-10,3805$ & $0,0000^{*}$ \\
4 & Inflasi & $-0,93313$ & 0,0600 \\
\hline
\end{tabular}

Sumber : Output Regresi

Keterangan : ** Signifikan pada taraf 5\%, ***

Signifikan pada taraf $1 \%$

Berdasarkan hasil penelitian menunjukkan bahwa ekspor berpengaruh positif dan signifkan pada level 1 persen terhadap cadangan devisa di Indonesa tahin 2011 sampai dengan 2018. Hal ini menunjukkan bahwa semakin meningkatnya ekspor maka akan meningkatkan cadangan devisa. Hal ini disebabkan dalam kegiatan ekspor suatu negara pastinya akan mendapatkan jumlah uang dalam bentuk valuta asing atau bisa dikatakan devisa, ini salah satu dari pemasukan negara.

Hasil penelitian ini sesuai dengan penelitian yang dilakukan oleh Agustina dan Reny (2014) yang menyatakan bahwa Ekspor berpengaruh signifikan positif terhadap Cadangan Devisa. Hal ini sejalan dengan penelitian Rochman (2009), Benny (2013), Putri, et al (2017), Putra \& Damanik (2017), Dani (2020), dan Soekapdjo \& Danova (2020). Apabila Indonesia sering melakukan ekspor barang ke negara lain maka Indonesia akan memperoleh devisa dari negara pengimpor, jadi semakin banyak barang yang diekspor, maka devisa yang akan diperoleh juga semakin banyak. Dengan semakin meningkatnya nilai ekspor, maka menunjukkan bahwa negara tersebut semakin banyak menerima pemasukkan dari negara luar, atau biasa disebut menerima devisa atau valuta asing yang merupakan salah satu sumber pendapatan negara.

Berdasarkan hasil penelitian menunjukkan bahwa impor berpengaruh negatif dan signifkan pada level 1 persen terhadap cadangan devisa di Indonesa tahin 2011 sampai dengan 2018 impor mempunyai sifat yang berlawanan dengan ekspor. Hal ini menunjukkan apabila impor naik maka cadangan devisa akan turun. Hasil penelitian sesuai dengan penelitian yang dilakukan oleh Benny (2013), Uli (2016), Mahmudah (2019), dan Irawati \& Hariadi (2018) yang menunjukan bahwa impor berpengaruh negatif terhadap cadangan devisa. Artinya ketika impor meningkat maka posisi cadangan devisa akan menurun. Impor adalah perdagangan dengan cara memasukkan barang dari luar negeri ke dalam wilayah Indonesia. Impor mempunyai sifat yang berlawanan dengan ekspor. Kalau ekspor dapat dikatakan sebagai faktor "injeksi", maka impor justru merupakan "kebocoran" dalam pendapatan nasional.

Berdasarkan hasil penelitian menunjukkan bahwa inflasi tidak berpengaruh terhadap cadangan devisa. Jika Inflasi terjadi maka akan mengakibatkan kenaikan pada harga pangan dan minyak sehingga terhadi kesenjangan antar penawaran dan permintaan dimana arus impor akan meningkat dan arus ekspor akan terhambat ataupun mengalami penurunan terus menerus karena barang buatan dalam negeri jauh lebih mahal daripada harga barang sejenis buatan luar negeri. Pada akhirnya, hal itu akan mengakibatkan desifit neraca perdagangan Indonesia yang berdampak pada menurunnya Cadangan Devisa Indonesia.

Hasil penelitian sesuai dengan penelitian yang dilakukan oleh Sonia \& Setiawina (2016), Adiyadnya (2017), dan Masitha \& Pangidoan (2020), yang menunjukkan bahwa inflasi tidak berpengaruh terhadap cadangan devisa. Apabila harga-harga barang dan sektor jasa cenderung mengalami kenaikan atau disebut dengan inflasi, maka akan menyebabkan terhambatnya kegiatan perekonomian di negara bersangkutan. Sehingga negara membutuhkan lebih banyak devisa untuk dapat bertransaksi di luar negara. Pada akhirnya, hal itu akan mengakibatkan defisit neraca perdagangan Indonesia yang berdampak menurunnya Cadangan Devisa Indonesia.

\section{SIMPULAN}

Berdasarkan data yang diperoleh dalam penelitian mengenai pengaruh ekspor, impor dan inflasi terhadap cadangan devisa. Sampel pada penelitian ini berjumlah 96 bulan, kemudian telah dianalisa dengan menggunakan Regresi Linier Berganda dengan model OLS maka dapat didimpulkan bahwa 1) ekspor berpengaruh positif dan signifikan terhadap cadangan 
devisa, 2) impor berpengaruh negatif dan signifikan terhadap cadangan devisa, dan 3) inflasi tidak berpengaruh terhadap cadangan devisa. Temuan ini mengimplikasikan kebijakan 1) bahwa ekspor di Indonesia harus ditingkatkan, pemerintah dapat memberikan kebijakan-kebijakan kepada masyarakat khususnya yang akan melakukan ekspor, agar mendapat kemudahan dalam memenuhi syarat melakukan ekspor, 2) pemerintah harus menekan pertumbuhan impor. Misalnya dengan cara mengurangi impor produk-produk bermerk dan mengimpor bahan baku yang nantinya akan dipergunakan untuk keperluan ekspor. Rekomendasi untuk penelitian yang akan dilakukan selanjutnya untuk menambah variabel lain, serta menambahkan jangka waktu penelitian dengan harapan hasil yang diperoleh dapat lebih baik.

\section{DAFTAR PUSTAKA}

Adiyadnya, M. S. P. (2017). Analisis Pengaruh Inflasi, Kurs Dollar Amerika, Suku Bunga Kredit dan Utang Luar Negeri Terhadap Cadangan Devisa Indonesia Tahun 1996-2015. Jurnal Riset Akuntansi (JUARA), 7(1).

Agustina, A., \& Reny, R. (2014). Pengaruh Ekspor, Impor, Nilai Tukar, dan Tingkat Inflasi terhadap Cadangan Devisa Indonesia Tahun 2008-2012. Jurnal Wira Ekonomi Mikroski, 4(2): 61-70.

Amir, M, S. (2005). Ekspor-Impor Teori dan Penerapannya, Edisi Kesembilan, PT Pustaka Binaman Pressiondo, Jakarta.

Bank Indonesia 2019. Cadangan Devisa Indonesia. Jakarta.

Benny, J. (2013). Ekspor dan Impor Pengaruhnya Terhadap Posisi Cadangan Devisa di Indonesia. Jurnal EMBA: Jurnal Riset Ekonomi, Manajemen, Bisnis Dan Akuntansi, 1(4). https://doi.org/10.35794/emba.v1i4.2920

Dani, S. C. R. (2020). Pengaruh Ekspor Impor dan Nilai Tukar Rupiah Terhadap Cadangan Devisa Indonesia Tahun 2000-2019. Ecodunamika, 3(2).

Dananjaya, I, P, A, B., Jayawarsa, A, A, K., Purnami, A, A, S.(2019). Pengaruh Ekspor, Impor, Kurs Nilai Tukar Rupian, Dan Tingkat Inflasi Terhadap Cadangan Devisa Indonesia Periode 1999-2018. Warmadewa Economic Development Journal. 2(2). 64-71. Doi: http:// dx.doi.org/10.22225/wedj.2.2.1359.64- 71

Gujarati, D, N., \& Porter, D, C. (2011). Basic Econometric 5th Edition. McGraw -Hill: New York.

Irawati, N., TN, A.Z., \& Hariadi, S. (2018). Pengaruh Ekspor dan Impor Terhadap Posisi Cadangan Devisa Indonesia Periode 1991-2015. CALYPTRA, 7(2): 4281-4303.

Juniantara, I, P, K., \& dan Budhi, M, K, S. (2012). Pengaruh Ekspor, Impor, dan Kurs Terhadap
Cadangan Devisa Nasional Periode 1999-2010. EJurnal Ekonomi Pembangunan, 1(1): 32-38.

Kuswantoro, M. (2017). Analisis Pengaruh Inflasi, Kurs, Utang Luar Negeri, dan Ekspor Terhadap Cadangan Devisa Indonesia. Ekonomika, 12(1): 146-168.

Mahmudah, B. K. (2019). Pengaruh Ekspor Impor Terhadap Cadangan Devisa di Indonesia. Jurnal Ilmiah Akuntansi dan Keuangan, 8(1): 59-65.

Masitha, I. P., \& Pangidoan, E. (2020). Pengaruh Suku Bunga, Nilai Tukar Rupiah, Inflasi, Ekspor dan Impor Terhadap Cadangan Devisa di Indonesia. Jurnal Sains Ekonomi (JSE), 1(1): 1-8.

Putra, I. P. B. B., \& Indrajaya, I, G, B. (2013). Pengaruh Tingkat Inflasi, Utang Luar Negeri dan Suku Bunga Kredit terhadap Cadangan Devisa Indonesia tahun 1996-2011, E-Jurnal Ekonomi dan Pembangunan, 2(11): 492-546.

Putri, H. E., Indrawati, T., \& Widayatsari, A. (2017). Pengaruh Ekspor, Penanaman Modal Asing, dan Utang Luar Negeri Terhadap Cadangan Devisa di Indonesia. JOM Fekon, 4(1): 240-252.

Putra, M. U. M., \& Damanik, S. (2017). Pengaruh Ekspor Migas dan Non Migas Terhadap Posisi Cadangan Devisa di Indonesia. Jurnal Wira Ekonomi Mikroskil: JWEM, 7(2): 245-254.

Ridho, M. (2015). Pengaruh Ekspor, Hutang Luar Negeri dan Kurs Terhadap Cadangan Devisa Indonesia. e-Jurnal Perdagangan, Industri dan Moneter. 3(1): 1-9.

Rochman, A. M. (2009). Pengaruh Inflasi, Kurs Rupiah, Utang Luar Negeri Dan Ekspor Terhadap Cadangan Devisa Indonesia. E-Jurnal Perdagangan, Industri Dan Moneter, 3(1), 1-25.

Sugiyono, S. (2012). Metode Penelitian Administrasi. Alfabeta. Bandung.

Suliyanto, S. (2011). Ekonomika terapan: Teori dan Aplikasi dengan SPSS. CV Andi Offset. Yogyakarta

Soekapdjo, S., \& Danova, G. K. (2020). Pengaruh Makro Ekonomi Terhadap Cadangan Devisa di ASEAN-5. Jurnal Ecodemica: Jurnal Ekonomi, Manajemen, dan Bisnis, 4(1): 68-76.

Sonia, A. P., \& Setiawina, N. D. (2016). Pengaruh Kurs, JUB, dan Tingkat Inflasi Terhadap Ekspor, Impor dan Cadangan Devisa Indonesia. Jurnal EP Unud, 5(10): 1077-1102.

Uli, L. B. (2016). Analisis Cadangan Devisa Indonesia. Jurnal Perspektif Pembiayaan dan Pembangunan Daerah,4(1): 15-24. 